Check for updates

Cite this: RSC Adv., 2017, 7, 18946

Received 17th January 2017

Accepted 16th March 2017

DOI: $10.1039 / \mathrm{c} 7 \mathrm{ra00722a}$

rsc.li/rsc-advances

\section{Stability of carbon and nitrogen isotopic compositions of the protein extracted from milk and their potential as "fingerprints" of geographical origin}

\author{
Hao Dong, $\mathbb{D} \dagger^{\mathrm{a}}$ Kaijun Xiao $\dagger^{* a}$ and Donghui Luo $\dagger^{\mathrm{b}}$
}

The present work aimed to determine whether isotopic compositions can be used as "fingerprints" in identifying the geographical origin of milk. For this purpose, $\delta^{13} \mathrm{C}$ and $\delta^{15} \mathrm{~N}$ values of the proteins extracted from fifty-six Tetra Pak milk samples originating from four continents, including Australia (with New Zealand), Europe (Germany and France), North America (the United States) and Asia (China), were determined using elemental analyzer-isotope ratio mass spectrometry (EA-IRMS). The effects of storage time and temperature on the $\delta^{13} \mathrm{C}$ and $\delta^{15} \mathrm{~N}$ values were also studied in order to evaluate the stability of the isotopic composition and hence the ability of the developed EA-IRMS method to identify the geographical origin of milk. The results indicated that there were no significant differences $(P>0.05)$ for $\delta^{13} \mathrm{C}$ and $\delta^{15} \mathrm{~N}$ values for the samples stored under different conditions, demonstrating the stability of the isotopic compositions in the proteins extracted from these milk samples. The $\delta^{13} \mathrm{C}$ values of these extracted proteins ranged from $-29.36 \%$ to $-15.02 \%$. Their mean $\delta^{15} \mathrm{~N}$ values were calculated to be between $4.55 \%$ o and $5.80 \%$, with the highest, second-highest, third-highest, and lowest values for the samples from Australia (with New Zealand), Europe, America, and Asia, respectively. Significant differences $(P<0.05)$ were found in the $\delta^{13} \mathrm{C}$ and $\delta^{15} \mathrm{~N}$ values between these four regions, verifying their potential as "fingerprints" of the geographical origin of milk. The results obtained confirm the suitability and potential of stable isotopic composition $\left(\delta^{13} \mathrm{C}\right.$ and $\left.\delta^{15} \mathrm{~N}\right)$ analysis in determining the geographical origin of milk.

\section{Introduction}

Food adulteration and mislabeling have become two of the most serious problems in the food industry due to the low transport costs and increasing mobility of foodstuffs. Generally, food products that are of high quality or that originated from certain geographical regions can be sold at premium prices. ${ }^{1}$ However, some cheaper food products are always mislabeled as more valuable ones in order to yield greater profits, leading to an unfair and dishonest food market. This circumstance on the one hand threatens the livelihood of honest traders, and on the other hand infringes the rights of consumers. ${ }^{2}$ Fortunately, in recent decades, consumers have been paying increasing attention to the geographical origin of food products mainly because of its associations with food quality and food authenticity. ${ }^{3-5}$ Hence, it is of great importance to take measures to identify the geographical origin of food products. ${ }^{6}$

\footnotetext{
${ }^{a}$ School of Food Science and Technology, South China University of Technology, Guangzhou 510640, China. E-mail: 516410953@163.com; fekjxiao@scut.edu.cn ${ }^{b}$ Guangzhou Healthy Food Technology Co., Ltd., Guangzhou, 510640, China

$\dagger$ Current address: No. 381, Wushan Road, Tianhe District, Guangzhou, China, Tel: +86-20-87113843; Fax: +86-20-87113843.
}

In 2001, Almeida \& Vasconcelos (2001) adopted a relatively new technology, stable isotope ratio analysis, to identify the authenticity of wine provenance in the European wine industry. ${ }^{6,7}$ This technology has since been widely and successfully used to detect adulterations of food products such as honey, ${ }^{8-11}$ fruit juices, ${ }^{12,13}$ oils and cheese, ${ }^{\mathbf{1 4 , 1 5}}$ and dairy products, ${ }^{6,16,17}$ as well as a few other food products. ${ }^{5,18,19}$

The isotope pairs most commonly measured when assessing the origin of a food product are the light element isotope pairs ${ }^{2} \mathrm{H} /{ }^{1} \mathrm{H},{ }^{13} \mathrm{C} /{ }^{12} \mathrm{C},{ }^{15} \mathrm{~N} /{ }^{14} \mathrm{~N},{ }^{18} \mathrm{O} /{ }^{16} \mathrm{O}$ and ${ }^{34} \mathrm{~S} /{ }^{32} \mathrm{~S}$ and the heavy element isotope pair ${ }^{87} \mathrm{Sr} /{ }^{86} \mathrm{Sr} .{ }^{15}$ Physical, chemical, and biochemical processes could result in isotopic fractionation, leading to changes in the relative abundance of stable isotopes in different environmental conditions. A range of factors such as latitude, climate and agricultural practices could affect the degree of isotopic fractionation for the light elements. ${ }^{6}$ As for animal products, the stable isotopic composition of the tissues of the animals generally reflects the stable isotopic compositions of their ingested foods. ${ }^{15,20}$ Hence, the milk from cows with pastures as their main food source will directly reflect the stable isotope ratios in that particular region. ${ }^{21}$ Unfortunately, analysis of individual stable isotope ratios is insufficient to provide unequivocal and robust information about the origin of 
food products. However, analysis of multiple stable isotope ratios allows a stable isotopic "fingerprint" for the food product from the particular geographical region to be reliably developed.

Determination of the geographical origin of milk and milk products and the evaluation of their quality have recently become possible. ${ }^{6,16,20,22,23}$ It was reported that the geographical origin of milk samples from different regions of Europe could be identified by measuring the stable isotope ratios of oxygen $\left(\delta^{18} \mathrm{O}\right)$ in milk water which evaporated from milk sample and the nitrogen $\left(\delta^{15} \mathrm{~N}\right)$ and carbon $\left(\delta^{13} \mathrm{C}\right)$ isotope contents of specific milk fractions in the samples. ${ }^{20}$ However, to the best of our knowledge, there has been no published report of the ability to identify the geographical origin of milk from more than one continent. In addition, the stability of using isotopic compositions to identify the geographical origin of food needs to be determined. Hence, the aim of the present study was to identify the detailed geographical origin of milk samples from countries of four continents (specifically Australia and New Zealand, Germany and France, the United States, and China) using the isotopic compositions of the protein extracted from the milk as the "fingerprints". Moreover, the effects of storage conditions on the $\delta^{13} \mathrm{C}$ and $\delta^{15} \mathrm{~N}$ values of the extracted milk protein were also investigated. The results obtained in this work confirmed the stability of these isotopic compositions in milk and the hence the potential of analyzing the isotopic composition in a milk sample for the purpose of determining its geographical origin.

\section{Materials and methods}

\section{Materials, chemicals and samples}

The casein having $\delta^{13} \mathrm{C}$ values of $-26.98 \% \pm 0.15 \%(n=10)$ and $\delta^{15} \mathrm{~N}$ values of $5.94 \% \pm 0.20 \%(n=10)$ was chosen for the standards of carbon and nitrogen isotope ratio analysis. Milli-Q water $(18.2 \mathrm{M} \Omega \mathrm{cm})$ was used in the whole experiment. Other chemicals used in the present work were of analytical grade and purchased from Guangzhou Chemical Reagent Factory (Guangzhou, China).

Fifty-six Tetra Pak milk samples originating from four continents including Australia and vicinity (fifteen samples mainly obtained from Australia and New Zealand), Europe (fourteen samples mainly obtained from Germany and France), North America (twelve samples mainly obtained from the United States) and Asia (fifteen samples mainly obtained from China) were collected in April and May of 2015. Additionally, four milk samples, labeled as samples \#1 to \#4, were provided by a dairy manufacturer in Guangzhou, China to conduct the stability experiments.

\section{Instrumentation}

An MS3 basic vortex mixer (IKA GmbH, Germany) was used for vortexing. A 5804R centrifuge (Eppendorf Corp., Germany) was used to extract protein from the milk samples. The stable carbon and nitrogen isotopic compositions of the protein extracted from the milk samples were determined by performing elemental analyzer-isotope ratio mass spectrometry (EA-IRMS) using a DELTA V PLUS IRMS (Thermo Electron Corporation) interfaced with a Flash 2000 element analyzer (Thermo Electron Corporation). All samples and standard materials were measured after the balance of reference gases $\left(\mathrm{CO}_{2}\right.$ and $\left.\mathrm{N}_{2}\right)$. The standard deviations (SD) were less than $0.06 \%(n=10)$ and $0.08 \%(n=10)$ for $\mathrm{CO}_{2}$ and $\mathrm{N}_{2}$, respectively. A Milli-Q A10 gradient system (Millipore Co., Bedford, USA) was used to produce Milli-Q water $(18.2 \mathrm{M} \Omega \mathrm{cm})$.

\section{Sample preparation}

For each experiment, $10 \mathrm{~g}$ of the milk sample, $4 \mathrm{~mL}$ of distilled water and $4 \mathrm{~mL}$ of a $6 \%$ hydrochloric acid solution were placed in a $50 \mathrm{~mL}$ centrifuge tube and vortexed. Then the tube was swirled in a water bath at $80{ }^{\circ} \mathrm{C}$ until visible floc formed and clear supernatant was observed. If no visible floc formed, or if the supernatant remained turbid, acid was added in $2 \mathrm{~mL}$ increments with heating repeated between additions. The tube was centrifuged at $4000 \mathrm{rpm}$ and the supernatant was removed. The precipitate was washed by combining it with $50 \mathrm{~mL}$ of Milli$\mathrm{Q}$ water, and the resulting mixture was vortexed and then centrifuged at $4000 \mathrm{rpm}$, after which the supernatant was removed. This procedure was repeated at least five times until the supernatant was clear. The precipitated protein was freezedried and ground to a fine powder prior to EA-IRMS analysis. As for the stability experiments, immediately after sample \#1 and sample \#2 were produced, portions of each of these two samples were stored at room temperature for three, six, nine and twelve months. Portions of sample \#3 and sample \#4 were stored at $4{ }^{\circ} \mathrm{C}, 20^{\circ} \mathrm{C}$, and $37^{\circ} \mathrm{C}$ for three and six months, respectively. The protein extracted from the milk samples stored for various durations and at various temperatures were prepared according to the method described above, and their stable carbon and nitrogen isotopic compositions were analyzed using EA-IRMS.

\section{Standards}

The $\delta$ notation was used to describe the isotopic difference between the sample and an international standard, and was defined according to the formula

$$
\delta(\%)=\left(R_{\mathrm{s}}-R_{\mathrm{std}}\right) / R_{\mathrm{std}} \times 1000
$$

where $R_{\mathrm{S}}$ is the isotope ratio (i.e., ${ }^{13} \mathrm{C} /{ }^{12} \mathrm{C},{ }^{15} \mathrm{~N} /{ }^{14} \mathrm{~N}$ ) of the sample, and $R_{\text {std }}$ is that of the reference material. Variations in stable isotope ratios were reported as parts per thousand $(\%)$ deviations from internationally accepted standards: with the Vienna Pee Dee Belemnite (VPDB) standard used for carbon, and atmospheric nitrogen (air) for nitrogen. Each sample was analyzed three times and the mean value was calculated and reported. The analysis was repeated if the difference between the two values was greater than $0.200 \%$ for both $\delta^{13} \mathrm{C}$ and $\delta^{15} \mathrm{~N}$ values. In addition, the values were referenced against reference gases $\left(\mathrm{N}_{2}, \mathrm{CO}_{2}\right)$ previously calibrated against International Standards (IS) from the International Atomic Energy Agency (IAEA). Moreover, for each 


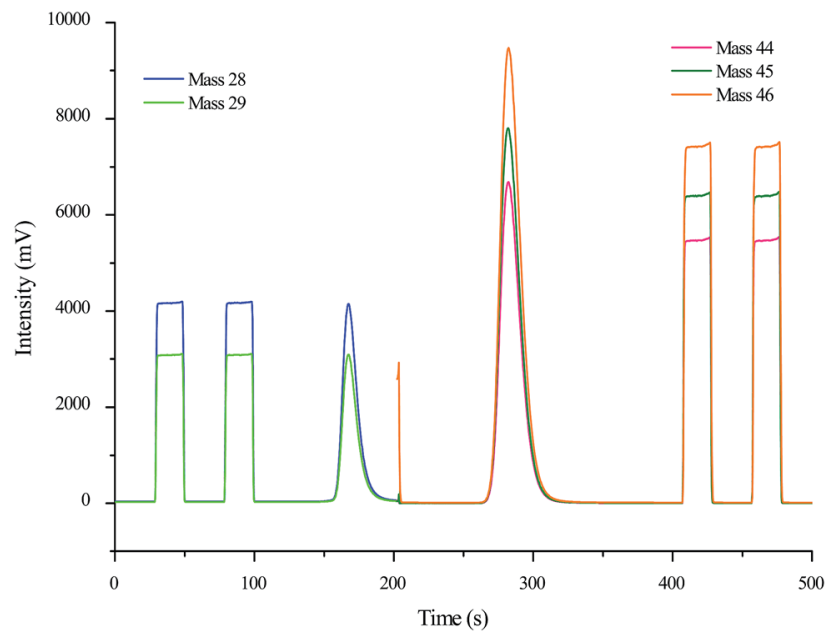

Fig. 1 Chromatogram of the protein extracted from a milk sample acquired by performing EA-IRMS using the one-step method.

run, at least one in-house standard was analyzed to check the accuracy of the analysis.

\section{Measurement of stable carbon and nitrogen isotope ratios}

For each experiment, a mass of approximately $1 \mathrm{mg}$ of the powdered protein extracted from the milk sample was placed into a small tin capsule $(3 \mathrm{~mm} \times 2 \mathrm{~mm} \times 5 \mathrm{~mm})$. Then the capsule was folded and compressed to contain the sample and minimize any air present. The prepared protein of the milk sample was introduced into the elemental analyzer using an auto-sampler and the stable carbon and nitrogen isotope ratios were measured by performing EA-IRMS using the previously published one-step method. ${ }^{5}$ The stable carbon and nitrogen isotopic compositions were recorded in the delta $(\delta)$ notations relative to the VPDB standard and the air standard, respectively. Due to the increased amount of sample, the dilutor was switched on just prior to the elution of the $\mathrm{CO}_{2}$ peak and switched off immediately afterwards to prevent the detector from being overloaded with $\mathrm{CO}_{2}$. The $\mathrm{CO}_{2}$ reference gas and $\mathrm{N}_{2}$ reference gas were calibrated against the casein standard. ${ }^{7,8}$ Each sample was analyzed a minimum of three times and the mean value was calculated and reported. A chromatogram of the protein extracted from a milk sample and measured using the one-step method is shown in Fig. 1.

\section{Statistical analysis}

Data were analyzed using SPSS (SPSS Inc., Chicago, IL, USA) and presented as mean \pm SD with triplicates. Significance was determined at $P<0.05$ by carrying out an analysis of variance (ANOVA) followed by a Duncan's least significant difference test.

\section{Results and discussion}

Effects of different storage conditions on the $\delta^{13} \mathrm{C}$ and $\delta^{15} \mathrm{~N}$ values of protein extracted from milk

$\delta^{13} \mathrm{C}$ and $\delta^{15} \mathrm{~N}$ values of the protein extracted from the milk samples stored at room temperature for three, six, nine and twelve months are presented in Table 1 . From the results, there was no significant $(P>0.05)$ difference between the $\delta^{15} \mathrm{~N}$ values of extracted proteins stored for the various durations and that for the control except for the extracted proteins stored for three months. As for the $\delta^{15} \mathrm{C}$ values, no significant $(P>0.05)$ differences were observed between extracted proteins stored for different durations and the control. These results confirmed the stability of the isotopic compositions in the extracted protein of milk stored for various durations. The $\delta^{13} \mathrm{C}$ value has been reported to exhibit a strong influence on the ecology, and $\delta^{15} \mathrm{~N}$ in plants has been reported to be primarily controlled by regional agricultural practices. ${ }^{24}$ Moreover, the $\delta^{13} \mathrm{C}$ values in plants were previously reported to be correlated with the ratio of intercellular $\mathrm{CO}_{2}$ to $\mathrm{CO}_{2}$ from the environment. ${ }^{25}$ The same researchers also demonstrated that the association of higher altitude with lower concentrations of atmospheric $\mathrm{CO}_{2}$ may result in different intensities of physiological processes and different $\delta^{13} \mathrm{C}$ values in wheat and other plants. It has been reported that the nitrogen cycling processes played a strong role in the overall relationship between $\delta^{15} \mathrm{~N}$ values in soil and plants, and soil containing nitrogen sources was the main source of nitrogen for plants. ${ }^{26}$ Moreover, nitrogen cycling processes were reported to play a strong role in the overall relationship between $\delta^{15} \mathrm{~N}$ values in soil and plants. ${ }^{26}$ Therefore, a range of factors including latitude, climate, and agricultural practices could affect the degree of fractionation and further influence the stable isotopic compositions in plants and animals, and even in dairy products and some other foods.

We also investigated the effect of storage temperature on the $\delta^{13} \mathrm{C}$ and $\delta^{15} \mathrm{~N}$ values of the protein extracted from the milk. From the results (Table 2), no significant $(P>0.05)$ difference was observed amongst the $\delta^{13} \mathrm{C}$ and $\delta^{15} \mathrm{~N}$ values for milk stored at $4{ }^{\circ} \mathrm{C}, 20{ }^{\circ} \mathrm{C}$ and $37^{\circ} \mathrm{C}$. Hence, results about the variation of $\delta^{13} \mathrm{C}$ and $\delta^{15} \mathrm{~N}$ values of the samples stored under different conditions demonstrated the stability of stable isotopic compositions in the extracted protein of milk and their potential as "fingerprints" in tracing the geographical origin of milk stored under different conditions.

\section{$\delta^{13} \mathrm{C}$ analysis of the extracted proteins of fifty-six milk samples from four continents}

The $\delta^{13} \mathrm{C}$ values of the extracted proteins of milk originating from four different continents are shown in Fig. 2. The $\delta^{13} \mathrm{C}$ values of the extracted proteins from Australia (and New Zealand) were observed to be in the range -29.36 to $-27.28 \%$, with the average value being $-28.76 \%$, while those from Asia (specifically, China) were found to be in the range -16.71 to $-15.02 \%$, with the average value being $-15.99 \%$. The stable isotopic compositions of cow tissues and even milk from cows have been reported to mirror the stable isotopic compositions of foods they eat and ingest. ${ }^{15,21}$ That is to say, the stable isotopic compositions of milk from cows with different pastures are directly determined by the stable isotopic compositions of the different geographical origins. Some scientists have reported that $\delta^{13} \mathrm{C}$ values of full honey and its protein fraction could be effectively used to identify adulteration of honey. ${ }^{10}$ This ability is 
Table $1 \delta^{13} \mathrm{C}$ and $\delta^{15} \mathrm{~N}$ values of the protein extracted from milk stored at room temperature for different numbers of months $(n=6)^{a}$

\begin{tabular}{|c|c|c|c|c|c|c|}
\hline \multicolumn{2}{|c|}{ Storage time (months) } & \multirow{2}{*}{$\begin{array}{l}\text { Control }(0) \\
-15.63 \pm 0.12^{\mathrm{a}}\end{array}$} & \multirow{2}{*}{$\frac{3}{-15.78 \pm 0.09^{\mathrm{a}}}$} & \multirow{2}{*}{$\frac{6}{-15.46 \pm 0.10^{\mathrm{a}}}$} & \multirow{2}{*}{$\frac{9}{-15.66 \pm 0.15^{\mathrm{a}}}$} & \multirow{2}{*}{$\frac{12}{-15.51 \pm 0.14^{\mathrm{a}}}$} \\
\hline Sample \#1 & $\delta^{13} \mathrm{C}$ value $(\%)$ & & & & & \\
\hline & $\delta^{15} \mathrm{~N}$ value $(\%)$ & $4.56 \pm 0.21^{\mathrm{a}}$ & $4.70 \pm 0.18^{\mathrm{b}}$ & $4.60 \pm 0.12^{\mathrm{ab}}$ & $4.52 \pm 0.24^{\mathrm{a}}$ & $4.58 \pm 0.11^{\mathrm{a}}$ \\
\hline & $\delta^{15} \mathrm{~N}$ value $(\%)$ & $4.45 \pm 0.18^{\mathrm{a}}$ & $4.41 \pm 0.16^{\mathrm{a}}$ & $4.48 \pm 0.15^{\mathrm{a}}$ & $4.51 \pm 0.16^{\mathrm{a}}$ & $4.44 \pm 0.20^{\mathrm{a}}$ \\
\hline
\end{tabular}

${ }^{a}$ The data are expressed as means \pm SD with triplicates. Values within the same row with different letters are significantly different $(P<0.05)$; otherwise values are not significantly different $(P>0.05)$.

Table $2 \delta^{13} \mathrm{C}$ and $\delta^{15} \mathrm{~N}$ values of the protein extracted from milk stored at $4{ }^{\circ} \mathrm{C}, 20^{\circ} \mathrm{C}$ and $37^{\circ} \mathrm{C}$ for three and six months $(n=6)^{a}$

\begin{tabular}{|c|c|c|c|c|}
\hline Storage temperature $\left({ }^{\circ} \mathrm{C}\right)$ & & 4 & 20 & 37 \\
\hline \multirow[t]{2}{*}{ Sample \#3 (3 months) } & $\delta^{13} \mathrm{C}$ value $(\%)$ & $-16.67 \pm 0.14^{\mathrm{a}}$ & $-16.58 \pm 0.13^{\mathrm{a}}$ & $-16.63 \pm 0.10^{\mathrm{a}}$ \\
\hline & $\delta^{15} \mathrm{~N}$ value $(\%)$ & $4.41 \pm 0.18^{\mathrm{a}}$ & $4.78 \pm 0.15^{\mathrm{b}}$ & $4.46 \pm 0.12^{\mathrm{a}}$ \\
\hline & $\delta^{15} \mathrm{~N}$ value $(\%)$ & $4.68 \pm 0.20^{\mathrm{a}}$ & $4.72 \pm 0.17^{\mathrm{a}}$ & $4.62 \pm 0.21^{\mathrm{a}}$ \\
\hline
\end{tabular}

${ }^{a}$ The data are expressed as means \pm SD with triplicates. Values within the same row with different letters are significantly different $(P<0.05)$, otherwise, values are not significantly different $(P>0.05)$.

due to honey preferring pollen from C3 plants while the most common adulterations of honey mainly use the $\mathrm{C} 4$ sugar addition. ${ }^{9}$ The carbon isotopic composition of plant materials strongly depends on the type of carbon fixation process used, be it the C3, C4 or crassulacean acid metabolism (CAM) cycle. ${ }^{27,28}$ Different photosynthesis pathways present biological discrimination effects on the carbon fixation process, and hence yield different ${ }^{13} \mathrm{C} /{ }^{12} \mathrm{C}$ ratios in different kinds of plants; accordingly, the $\delta^{13} \mathrm{C}$ values of plants using the $\mathrm{C} 3$ cycle and $\mathrm{C} 4$ cycle have been shown to range from $-22 \%$ to $-33 \%$ and $-10 \%$ to $-20 \%$, respectively, while the range of $\delta^{13} \mathrm{C}$ values of plants using the CAM cycle has been shown to be wider. ${ }^{5,24,27}$ Indeed, as shown in Fig. 2, the milk samples originating from cows in Asia, grazing on pastures using the $\mathrm{C} 4$ cycle, yielded $\delta^{13} \mathrm{C}$ values between
$-10 \%$ and $-20 \%$. Samples originating from Australia (and New Zealand) were derived from cows grazing on pastures using the C3 cycle. Unfortunately, it was difficult to use $\delta^{13} \mathrm{C}$ values to distinguish the extracted proteins of milk from Europe from those of milk from America since their $\delta^{13} \mathrm{C}$ values overlapped, i.e., they ranged from $-21.36 \%$ to $-21.02 \%$ and from $-22.98 \%$ to $-21.52 \%$, respectively (Fig. 2). Thus, further statistical investigations based on a larger number of samples from these regions or measuring other isotopic compositions are required.

\section{$\delta^{15} \mathrm{~N}$ analysis of the extracted proteins of fifty-six milk samples from four different continents}

The mean $\delta^{15} \mathrm{~N}$ values of the extracted proteins of fifty-six milk samples from the four different continents were calculated to be

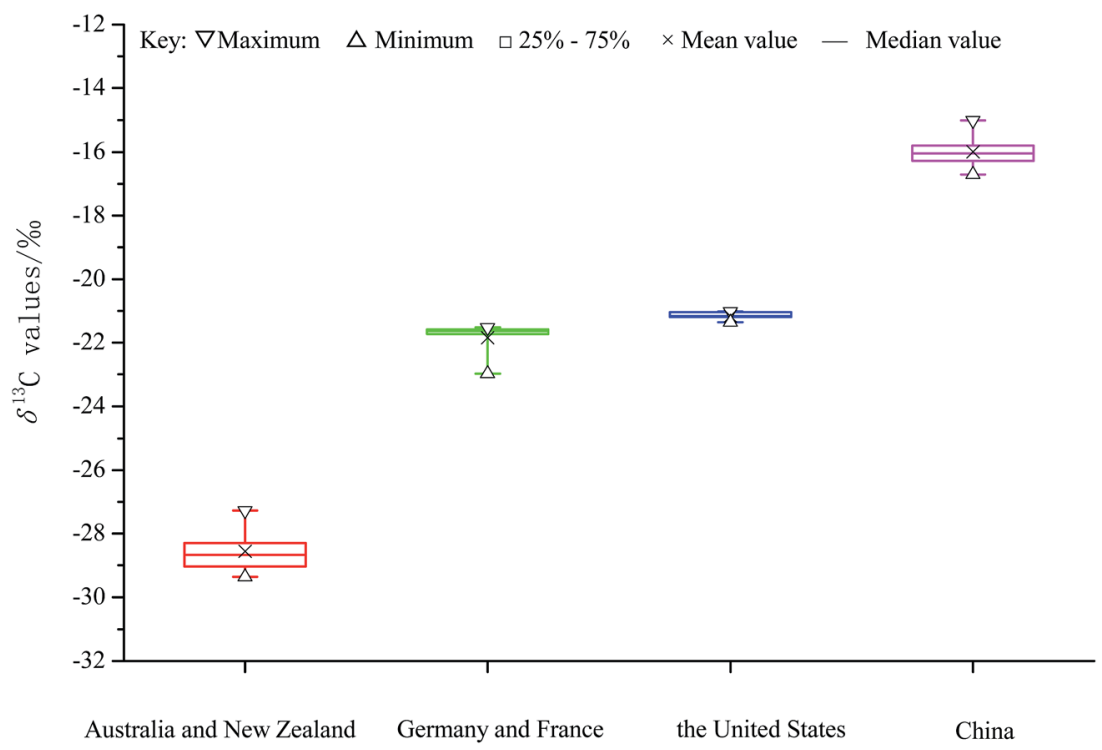

Fig. $2 \delta^{13} \mathrm{C}$ values of the protein fractions extracted from fifty-six milk samples of different continents by geographical origin. 


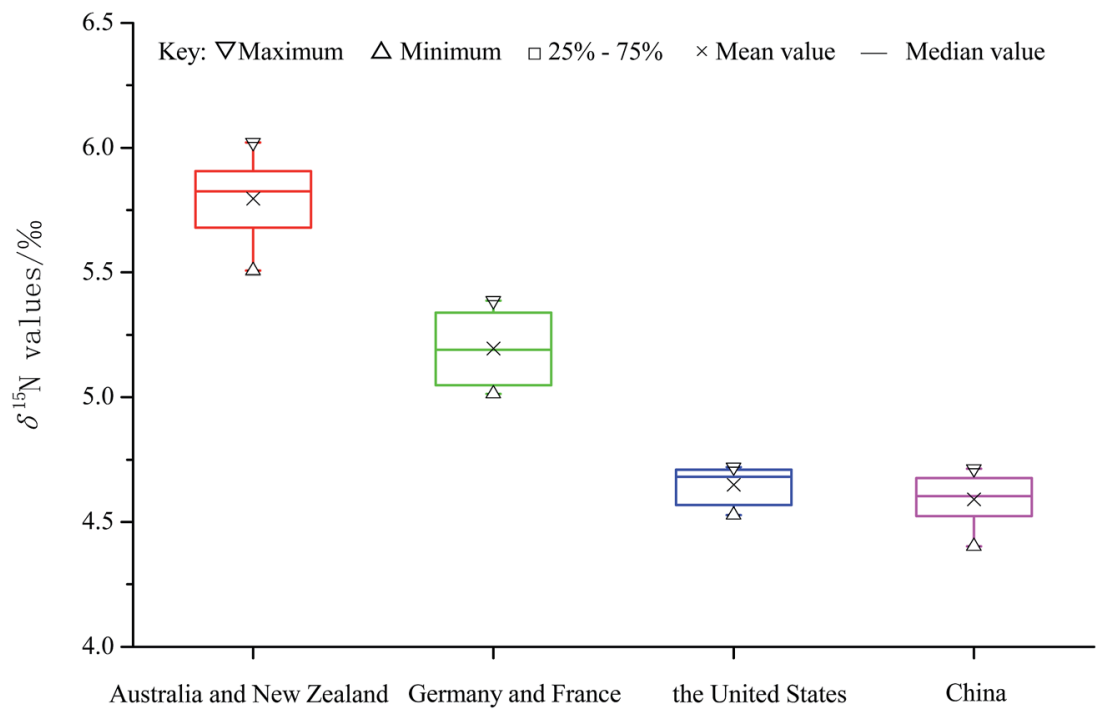

Fig. $3 \delta^{15} \mathrm{~N}$ values of the protein fractions extracted from fifty-six milk samples of different continents by geographical origin.

between $4.55 \%$ and $5.80 \%$, with the highest, second-highest, third-highest, and lowest values for Australia (with New Zealand), Europe, America, and Asia, respectively (Fig. 3); this order was completely opposite that of the $\delta^{13} \mathrm{C}$ values of milk (Fig. 2) whose highest, second-highest, third-highest, and lowest values were for Asia, America, Europe, and Australia (with New Zealand), respectively. Moreover, as shown in Fig. 3, the ranges of the $\delta^{15} \mathrm{~N}$ values were quite different for the samples from the different continents, except for those from America and Asia: the $\delta^{15} \mathrm{~N}$ values ranged from $5.51 \%$ to $6.02 \%$ for Australia (with New Zealand), $5.01 \%$ to $5.39 \%$ for Europe, $4.57 \%$ to $4.72 \%$ for America, and $4.40 \%$ to $4.71 \%$ for Asia group. A $P$-value analysis indicated that there were significant differences in the $\delta^{15} \mathrm{~N}$ values between these four continents $(P<0.05)$. As can be seen in Fig. 3, the samples from Australia (with New Zealand) and those from Europe could be easily distinguished from each other and the other groups based on the $\delta^{15} \mathrm{~N}$ values, but unfortunately, there was a large overlap between the $\delta^{15} \mathrm{~N}$ values of the samples from America and those from Asia. In addition, a broad distribution of $\delta^{15} \mathrm{~N}$ values was observed for the samples from Australia (with New Zealand) and from Europe, and the standard deviations for these two groups were found to be even bigger than those for the other two groups. The broad distributions of $\delta^{15} \mathrm{~N}$ values for the samples from Australia (with New Zealand) and from Europe may be explained by noting that the sampling in Australia and New Zealand, and in Germany and France, did not cover all the growing regions but only representative locations that were relatively far from each other geographically.

It was previously reported by researchers that the geographical origin of pure milk could be identified from the $\delta^{15} \mathrm{~N}$ and $\delta^{13} \mathrm{C}$ values of the extracted protein, or from the $\delta^{2} \mathrm{H}$, and $\delta^{18} \mathrm{O}$ values of milk water; they also found that the $\delta^{13} \mathrm{C}$, $\delta^{15} \mathrm{~N}, \delta^{2} \mathrm{H}$ and $\delta^{18} \mathrm{O}$ values taken together could indicate the detailed regions from which the pure milk originated. ${ }^{16}$ In addition, the nitrogen isotopic composition in plants was reported to be influenced by the intensity of agricultural use, ${ }^{16}$ the climate conditions, and fluctuations in temperature and precipitation. ${ }^{24}$ Additionally, many studies reported the $\delta^{15} \mathrm{~N}$ values in plants to be highly related to the fertilizer used and the fertilization conditions where the plants grow. ${ }^{2,24,25,29}$ It has also been reported that the synthetic nitrogen fertilizers generally have $\delta^{15} \mathrm{~N}$ values between $-4 \%$ and $4 \%$ while the organic fertilizers have higher $\delta^{15} \mathrm{~N}$ values ranging from 2 to $30 \%$, and that different synthetic nitrogen fertilizers could show different $\delta^{15} \mathrm{~N}$ values..$^{27,30}$

\section{The distribution of carbon and nitrogen isotopic compositions of milk from different continents}

A two-dimensional distribution diagram of carbon and nitrogen isotopic compositions of the extracted proteins of milk samples

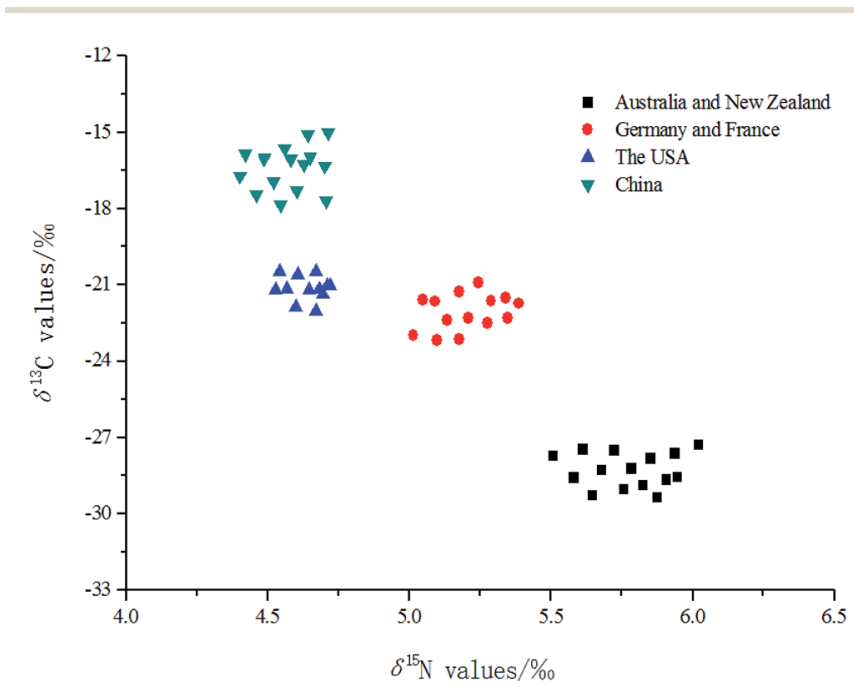

Fig. 4 The distribution of milk samples originating from four different continents based on the stable carbon and nitrogen isotopic compositions. 
from different regions is shown in Fig. 4. These distributions for the milk samples from the different continents concentrated in different parts of the plot. Moreover, the isolation of these concentrated regions was also found to be very significant. It has been reported in a previous work that the geographical origin of wheat from different regions could be easily identified by analyzing the two-dimensional distribution diagram based on the $\delta^{13} \mathrm{C}$ and $\delta^{15} \mathrm{~N}$ values of wheat. ${ }^{4}$ Moreover, stable isotopic composition analysis combined with a pentagonal radar plot, ${ }^{31}$ 3D scatter plot, ${ }^{16}$ and LDA $^{32,33}$ were successfully adopted in tracing the geographical origin of rice, wheat and some other foods. So, analyzing $\delta^{13} \mathrm{C}$ and $\delta^{15} \mathrm{~N}$ values could potentially be an interesting and rapid way of tracing the origin of a milk sample and hence maintain the normal operation of the milk market all over the world.

\section{Conclusions}

We determined stable carbon and nitrogen isotopic compositions $\left(\delta^{13} \mathrm{C}, \delta^{15} \mathrm{~N}\right.$ values) of extracted proteins from fifty-six milk samples from four continents (from several countries including Australia and New Zealand, Germany and France, the United States, and China), in order to develop a method to determine the geographic origin of milk. We also investigated the effects of storage time and temperature on $\delta^{13} \mathrm{C}$ and $\delta^{15} \mathrm{~N}$ values of the milk and the results indicated that there were no significant differences $(P>0.05)$ for $\delta^{13} \mathrm{C}$ and $\delta^{15} \mathrm{~N}$ values of the samples stored under different conditions. This result confirmed the stability of isotopic compositions in the extracted protein of milk and their potential use as "fingerprints" of the geographical origin of milk. We also found that there were significant differences between the mean $\delta^{13} \mathrm{C}$ and $\delta^{15} \mathrm{~N}$ values of the sample originating from different continents. The highest, second-highest, third-highest, and lowest $\delta^{15} \mathrm{~N}$ values were for the samples from Australia and New Zealand, Germany and France, the United States, and China, respectively; this trend was the reverse of that of the $\delta^{13} \mathrm{C}$ values, for which the highest, second-highest, third-highest, and lowest values were for samples from China, the United States, Germany and France, and Australia and New Zealand, respectively. It is clear from the obtained results that the $\delta^{13} \mathrm{C}$ and $\delta^{15} \mathrm{~N}$ values of analytes could potentially be used for a rapid and routine determination of the origin and species of milk. However, it is still uncertain whether the observed difference in isotopic compositions is generally applicable to all milk. A further statistical investigation based on a larger number of samples is thus necessary.

\section{Acknowledgements}

This work was financially supported by the Major Special Project of Industry-University-Research Collaborative Innovation of Guangzhou City (201508020086) and the Special Fund Project of Application-oriented for Science and Technology, Research and Development of Guangdong Province (2015B020230001). The authors would also like to thank all of the workers carrying out sampling and sample preparation, and taking measurements. Additionally, the authors gratefully acknowledge the Guangzhou Quality Supervision and Testing Institute for providing the real milk samples from all over the world.

\section{References}

1 H. Zhao, B. Guo, Y. Wei and B. Zhang, J. Cereal Sci., 2013, 57, 391-397.

2 S. Kelly, M. Baxter, S. Chapman, C. Rhodes, J. Dennis and P. Brereton, Eur. Food Res. Technol., 2002, 214, 72-78.

3 F. Camin, K. Wietzerbin, A. B. Cortes, G. Haberhauer, M. Lees and G. Versini, J. Agric. Food Chem., 2004, 52, 6592-6601.

4 D. Luo, H. Dong, H. Luo, Y. Xian, J. Wan, X. Guo and Y. Wu, Food Chem., 2015, 174, 197-201.

5 Y. Wu, D. Luo, H. Dong, J. Wan, H. Luo, Y. Xian, X. Guo, F. Qin, W. Han, L. Wang and B. Wang, Food Chem., 2015, 174, 553-557.

6 R. G. Crittenden, A. S. Andrew, M. LeFournour, M. D. Young, H. Middleton and R. Stockmann, Int. Dairy J., 2007, 17, 421428.

7 C. M. Almeida and M. T. S. D. Vasconcelos, J. Anal. At. Spectrom., 2001, 16, 607-611.

8 A. I. Cabañero, J. L. Recio and M. Rupérez, J. Agric. Food Chem., 2006, 54, 9719-9727.

9 H. Dong, D. Luo, Y. Xian, H. Luo, X. Guo, C. Li and M. Zhao, J. Agric. Food Chem., 2016, 64, 3258-3265.

10 D. Luo, H. Luo, H. Dong, Y. Xian, X. Guo and Y. Wu, Food Analytical Methods, 2016, 9, 255-262.

11 Y. Chen, D. Kong, L. Liu, S. Song, H. Kuang and C. Xu, Food Analytical Methods, 2016, 9, 905-914.

12 F. Guyon, P. Auberger, L. Gaillard, C. Loublanches, M. Viateau, N. Sabathié, M.-H. Salagoïty and B. Médina, Food Chem., 2014, 146, 36-40.

13 E. Jamin, F. Martin, R. Santamaria-Fernandez and M. Lees, J. Agric. Food Chem., 2005, 53, 5130-5133.

14 L. Pillonel, R. Badertscher, M. Casey, J. Meyer, A. Rossmann, H. Schlichtherle-Cerny, R. Tabacchi and J. O. Bosset, Int. Dairy J., 2005, 15, 547-556.

15 A. Rossmann, Food Rev. Int., 2001, 17, 347-381.

16 D. Luo, H. Dong, H. Luo, Y. Xian, X. Guo and Y. Wu, Food Analytical Methods, 2016, 9, 437-442.

17 J.-P. Renou, C. Deponge, P. Gachon, J.-C. Bonnefoy, J.-B. Coulon, J.-P. Garel, R. Vérité and P. Ritz, Food Chem., 2004, 85, 63-66.

18 D. Luo, H. Dong, Y. Xian, Y. Wu and X. Zeng, Food Analytical Methods, 2016, 9, 2400-2405.

19 T. Nietner, S. A. Haughey, N. Ogle, C. Fauhl-Hassek and C. T. Elliott, Food Res. Int., 2014, 60, 146-153.

20 B. E. Kornexl, T. Werner, A. Roßmann and H.-L. Schmidt, $Z$. Lebensm.-Unters. -Forsch. A, 1997, 205, 19-24.

21 A. Rossmann, G. Haberhauer, S. Hölzl, P. Horn, F. Pichlmayer and S. Voerkelius, Eur. Food Res. Technol., 2000, 211, 32-40.

22 D. Kong, L. Liu, S. Song, H. Kuang and C. Xu, Food Agric. Immunol., 2016, 27, 841-854. 
23 Y. Chen, L. Liu, S. Song, H. Kuang and C. Xu, Food Agric. Immunol., 2016, 27, 830-840.

24 S. Kelly, K. Heaton and J. Hoogewerff, Trends Food Sci. Technol., 2005, 16, 555-567.

25 H. Liu, B. Guo, Y. Wei, S. Wei, Y. Ma and W. Zhang, Food Chem., 2015, 171, 56-61.

26 D. M. Vallano and J. P. Sparks, Oecologia, 2013, 172, 47-58.

27 A. Guler, H. Kocaokutgen, A. V. Garipoglu, H. Onder, D. Ekinci and S. Biyik, Food Chem., 2014, 155, 155-160.

28 S. Wang, Q. Guo, L. Wang, L. Lin, H. Shi, H. Cao and B. Cao, Food Chem., 2015, 172, 669-674.
29 X. Liu, B. Guo, Y. Wei, J. Shi and S. Sun, Food Chem., 2013, 140, 135-140.

30 A. S. Bateman and S. D. Kelly, Isot. Environ. Health Stud., 2007, 43, 237-247.

31 Y. Suzuki, Y. Chikaraishi, N. O. Ogawa, N. Ohkouchi and T. Korenaga, Food Chem., 2008, 109, 470-475.

32 H. Zhao, B. Guo, Y. Wei and B. Zhang, J. Agric. Food Chem., 2012, 60, 10957-10962.

33 C. Li, H. Dong, D. Luo, Y. Xian and X. Fu, Food Analytical Methods, 2016, 9, 1512-1519. 